Article

\title{
Moving from Adaptive to Transformative Capacity: Building Foundations for Inclusive, Thriving, and Regenerative Urban Settlements
}

\author{
Gina Ziervogel ${ }^{1, *}$, Anna Cowen ${ }^{2}$ and John Ziniades ${ }^{2}$ \\ 1 Department of Environmental and Geographical Science, and African Climate and Development Initiative, \\ University of Cape Town, Cape Town 7700, South Africa \\ 2 Meshfield, P.O. Box 12698, Mill Street, Cape Town 8010, South Africa; anna@meshfield.com (A.C.); \\ john@meshfield.com (J.Z.) \\ * Correspondence: gina.ziervogel@uct.ac.za; Tel.: +27-21-6504796
}

Academic Editor: Patricia Romero-Lankao

Received: 31 May 2016; Accepted: 15 August 2016; Published: 20 September 2016

\begin{abstract}
The commitment to understanding the implications of a $1.5^{\circ} \mathrm{C}$ global temperature warming limit has contributed to a growing realisation that transformative adaptation is necessary to avoid catastrophic environmental and social consequences. This is particularly the case in urban settlements where disconnection from the systems that support life is pervasive and injustice and inequality play out daily. This paper argues that in order to transform towards thriving social-ecological systems, transformative capacity needs to be strengthened. The paper builds on the rich literature of adaptive capacity, alongside concepts of transformation that are drawn from resilience theory, organisational change, and developmental psychology. Reconnection to life-support systems, agency, and social cohesion are put forward as three foundational aspects of transformative capacity. A transdisciplinary case study of the FLOW programme in the Bergrivier Municipality, South Africa, is used to explore how transformative capacity has been built in practice. The case study explores an innovative programme that works with unemployed urban youth, alongside the exploration and introduction of a community currency in the informal business sector, and strengthening cross-scalar interaction between the local municipality and youth. The paper suggests that working across sectors and scales in a transdisciplinary manner is a challenging endeavour but necessary for building inclusive, thriving, and regenerative urban settlements.
\end{abstract}

Keywords: transformative capacity; adaptive capacity; agency; social cohesion; thrivability; South Africa

\section{Introduction}

Growing awareness that our fossil-fuelled, resource-depleting, poverty-exacerbating, and inequality-worsening way of life is no longer serving us, has prompted a plethora of "solutions" and strategies. The international commitment to limiting global average temperature increases to "well below $2{ }^{\circ} \mathrm{C}$ and pursuing efforts to limit the temperature increase to $1.5^{\circ} \mathrm{C}^{\prime}$, necessarily requires urgent, extensive and accelerated changes [1] (p. 3). Responses to increasing changes in both social and environmental systems are labelled by ever-shifting terminology, including sustainability, resilience, adaptation, and transformation. What is common among these terms is the attempt to answer some big questions, including: How can we live well together on this crowded planet that is experiencing increasing temperatures? What kind of world are we seeking to enact? What do we hope to transform to and what are the foundational capacities we need to develop in order to thrive in complexity, to bring into being this new world we hope for and imagine? 
The terms used in this field, particularly, but not exclusively, outside of academia, whilst useful to the degree to which they point to the ecological and social crises of our time, have lost their precision and meaning through overuse, and even abuse. Moreover, they are often co-opted by the very actors who perpetuate the polycrisis through their behaviours [2,3]. Thrivability, anti-fragility, regenerative design, bio-regionalism - all of these ideas speak of a new narrative that is emerging beyond traditional notions of "sustainability" and "resilience" and are finding traction in the framing of "transformation" [3]. The scientific community's commitment to understanding the implications of a $1.5^{\circ} \mathrm{C}$ limit on atmospheric warming has opened up an enquiry into the dynamics of transformative change.

Although it is clear that urban settlements are at the heart of the call for moving towards sustainability, resilience, and transformation, the focus, so far, has been on big cities [4-6]. Growing importance is being placed on the growth of small towns and cities, as well as city-regions $[7,8]$, where high concentrations of people and infrastructure are going to be situated in the future and where potential for transformation lies [5]. Pieterse [9] (pp. 22-23) highlights the important role that small and medium-sized cities will play in Africa's rapid urbanisation, which will happen less like "mega-city explosions" and more as a result of the "emergence of a number of significant city-region zones and corridors". Yet, less is written about these smaller sites, both in academic and practice-based literature $[7,10]$. In addition, in both big and small cities and towns, there is a lot more rhetoric about what should be done than practice-based examples [11].

Whilst this paper positions itself within the fields of urban sustainability, resilience, and climate change adaptation, it also tentatively seeks to speak more directly than our jargon, our discourses and our disciplinary fields sometimes allow. Of the three writers of this paper, only one is inside the academy, in the climate change adaptation field. The other two authors are scholar practitioners in the fields of architecture, urbanism, and technology. What binds us is a shared, and long-standing, interest in social change. We have, thus, engaged in transdisciplinary conversations that include, but are not bound by, the constraints of the current rules of academic knowledge production. Flavoured by this diversity, this paper addresses the question of how to undertake transdisciplinary research that can connect to policy and practice to affect adaptation, resilience, and transformation.

We chose to focus on the concept of transformation and put it at the heart of this paper. We suggest that the idea of "transformative capacity" is the capacity of individuals and organisations to be able to both transform themselves and their society in a deliberate, conscious way. This includes the capacity to imagine, enact, and sustain a transformed world and a way of life that is in balance with the carrying capacity of our earth, and where all life flourishes. We also propose that whilst it is necessary to have a sense of direction and of a goal (what are we transforming into), which has normative dimensions, it is equally important to cultivate an acceptance, even a delight, that one can never know, and that given the complexities of the current moment, there are few predictable outcomes [12].

To provide definitional clarity we start the next section by setting out how we view "transformation", drawing on the fields of social change, organisational change, and developmental psychology. We then contextualise our thinking by broadly locating our proposal for building "transformative capacity" in the climate change adaptation, social-ecological systems (SES), sustainability, and resilience discourses, tracing the move from reactive adaptation to deliberate transformation, from sustainability and resilience, to "thrivability", anti-fragility, and regenerative design.

We go on to propose that one can consciously cultivate "transformative capacity" by developing a set of new muscles (for some), or strengthening the muscles that are already there, yet underdeveloped. These muscles include (1) an awareness of and a reconnection to the visible systems, both natural (air, water, food, energy, biodiversity, ecosystems) and human-made (infrastructure, political, legal, and economic systems), that support our daily wellbeing; (2) a well-developed sense of one's own agency; and (3) strong social cohesion- "I belong, I am part of a community". Both agency and social cohesion are underpinned and supported by these visible systems. These three aspects 
could equally be framed as "a few foundations"; they are not intended to be exhaustive, but in our view, are central.

This paper uses the FLOW (Fostering Local Wellbeing) programme, a transdisciplinary research project in the Bergrivier Municipality, South Africa [13], to illustrate how transformative capacity has started to be developed in practice. Thus we first describe context, actors, and methodology, and then demonstrate how the project has begun to build transformative capacity across three central actor groups: civil society, business, and government. This is illustrated by describing aspects of the project implementation, namely an innovative leadership development programme that works with at-risk, unemployed youth (the FLOW Ambassadors), coupled with the exploration and introduction of a community currency, the Bergrivier Rand (BRAND), in the informal business sector and broadening of the understanding of local government potential through curated interactions between the local municipality and youth.

We conclude by summarising how the idea of "transformative capacity" can be built in a local urban context. This integrates concepts of both urban sustainability and urban resilience. We further argue that this type of work requires a transdisciplinary approach given the multiscalar and multidimensional challenges of learning to thrive in times of complexity and species-threatening global change.

\section{Defining Transformation}

It is with a slight sense of trepidation that we set out to define what we mean by transformation, given the vastness the term encompasses and the very many ways in which it is used and understood. There is also an inherent mystery to transformation, a quality noted time and time again by life-long students of change [14], something irreducible and transcending reason. As opposed to one definition, we thus sketch out a few contours, at various scales-societal, organisational, and individual.

It is widely acknowledged that we find ourselves in the midst of a profound societal transformation from a worldview that sees everything as mechanistic, linear, and deterministic, to a worldview that sees everything as living systems that are complex, adaptive, dynamic, emergent, interdependent, and never in equilibrium $[15,16]$. This new turning has been heralded for decades, and in different guises, and is most usefully viewed across the timescale of centuries, not decades. We are also still in the thick of this shift, with these two worldviews competing and overlapping, at all scales.

Another compelling narrative on societal change that is also emerging from and expands on the living systems view, is the view that one can look at and shape reality from a place of either scarcity or from abundance, and that the outcomes are substantively different. Amongst many others, McDonough and Braungart [17] enquire as to whether humanity could be $100 \%$ good, as opposed to "less bad", where every human action is generative and life-enhancing. Ritchie-Dunham [18] proposes Ecosynomics - the science of abundance-as a framework to highlight the assumptions of scarcity and abundance underlying human agreements. Eisenstein [19] and Lietaer [20] both demonstrate how our money system has contributed to alienation, competition, scarcity, destroyed community, and necessitated endless growth. And Kostakis and Bauwens [21] propose that we have it the wrong way around - our current political economy is based on a false idea of material abundance (which underpins our commitment to infinite growth) whilst simultaneously engineering immaterial scarcity (through the mechanism of intellectual property rights).

To begin to define transformation at the scale of the organisation, we look to the field of organisational change and, in particular, Edwards' work on organisational transformation for sustainability [14]. Summarising a wide reading of different definitions he defines organisational transformation as "discontinuous change that involves subjective and objective aspects of the whole multilevel organisational system and which results in a radical multidimensional reconfiguration of culture, systems and structures" [14] (p. 30).

Edwards goes on to stress that organisational transformation is intimately linked to individual transformation, seen as "the fundamental realignment of personal attitudes, consciousness, motivation, 
beliefs and spirituality" [14] (p. 31). Further work in the field of adult developmental psychology describes how individuals' capacity to construct meaning from the world around them develops as they move through life, from childhood through to old age [22]. Human meaning-making unfolds in defined sequential patterns or structures, as overlapping waves, not as steps in a ladder [23-25]. This psychological or cognitive development is characterised by an increasing capacity to hold more and more perspectives and to manage greater complexity. Transformation denotes the move from one level of development to another, and is distinct from "translation" which is the broadening and strengthening of capacities at a particular stage of development [23]. Educator and developmental psychologist Kegan suggests two essential concepts that contribute to healthy individual transformation: the first is the notion of "subject-object relations" and the second is the fundamental role that "support and challenge" plays in healthy development [22] (p. 34, p. 42). Using subject-object relation theory, Kegan proposes that human meaning-making is constantly shifting over time such that:

... what we take as subject and what we take as object are not necessarily fixed for us. They are not permanent. They can change. In fact transforming our epistemologies, liberating ourselves from that in which we are embedded, making what was subject into object so that we can 'have it' rather than 'be had' by it-this is the most powerful way I know to conceptualise the growth of the mind. [22] (p. 34)

In order to support healthy individual transformation, a healthy mix of support and challenge is also required.

Environments that are weighted too heavily in the direction of challenge without adequate support are toxic; they promote defensiveness and constriction. Those weighted too heavily towards support without adequate challenge are ultimately boring; they promote devitalisation. Both kinds of imbalance lead to withdrawal or dissociation from the context. In contrast, the balance of support and challenge leads to vital engagement [22] (p. 42).

Individual transformation is, therefore, essential in order to deal with the increasing levels of environmental and societal complexity we are facing.

\section{From Sustainability and Resilience to "Thrivability", from Adaptation to Deliberate Transformation}

Despite more than twenty years of climate talks, and more than forty years of sustainability awareness and practice, humanity finds itself in a far worse position than ever before, with many sustainability activists, advocates, practitioners, and academics overwhelmed by a sense of failure, coupled with an openness to reconceptualise societal responses to the polycrisis of climate change, ecological collapse, and growing social injustice and poverty [26,27]. At the core of this reconceptualising is a move from reactive, and often mechanistic, point solutions, conceived from a systems-in-equilibrium perspective, and implemented in a top-down, predict-and-control manner, to systems-wide transformation that is conceived from a non-equilibrium, non-linear view of systems, and is creative, adaptive, imbued with agency, and implemented through prototyping and social learning. This shift resonates with trends in the field of urban studies, where there is a growing emphasis on applying resilience theory to notions of urban sustainability [26,28-31]. This is also beginning to be articulated in the climate change adaptation field, with notions of transformational adaptation and deliberate transformation [32-35].

Applying resilience thinking to human settlement making and management is being proposed as a bridging or boundary concept [2,29]. It is also proposed as a possible solution to the paradox of sustainability and stability, evident in early notions of urban sustainability, where "sustainability was envisioned as a durable, stable, sometimes formulaic urban form that, once achieved, could persist for generations, for example through "smart growth" or "new urbanism", thinking that contradicts the reality of unpredictable disturbance and change [6] (p. 341). 
In terms of building capacity for urban resilience, Ahern [6] proposes a suite of strategies: multifunctionality, redundancy, and modularisation, (bio and social) diversity, multiscale networks and connectivity, and adaptive planning and design, implemented through a project by project "safe to fail" prototyping approach. Similar resilience-informed strategies are echoed by other urban theorists [36].

Whilst there is clearly rich potential and enormous value to this way of thinking about city making and sustaining, at root, it begs a set of questions: Who is doing the planning? Who owns? Who governs? Who maintains? Who pays? These questions of justice and equity need to be explicitly included, as they are often absent in urban resilience approaches [3,37,38]. From the perspective of a country like South Africa where for many, even their most basic needs (like safe drinking water and sanitation) are not met, how does one cultivate the mental and cultural receptivity to welcome ideas like urban wetlands and bio-swales for storm water management, when a concrete channel is easier to imagine, install, and maintain? Until we can successfully master integrating contesting meaning-making systems such as these, success will be limited and social injustice will prevail.

Caution is also needed when applying an ecologically-rooted concept to social systems that require a focus on human agency $[3,28]$. "In the social world, resilience has as much to do with shaping the challenges we face as [merely] responding to them" [29] (p. 306).

Concepts of sustainability and regenerative design as they apply to social and systemic change, in particular regarding urban settlements, can also be viewed as being on a continuum, moving from (unsustainable) conventional design, through green and sustainable design, to regenerative, participatory design as the most systemic and effective response. Figure 1 illustrates how fragmented and non-systemic tools and strategies (such as the various green-building rating tool systems) often yield results far short of the more difficult to implement regenerative design approaches that are rooted in co-production and the messiness of participatory planning and design [39].

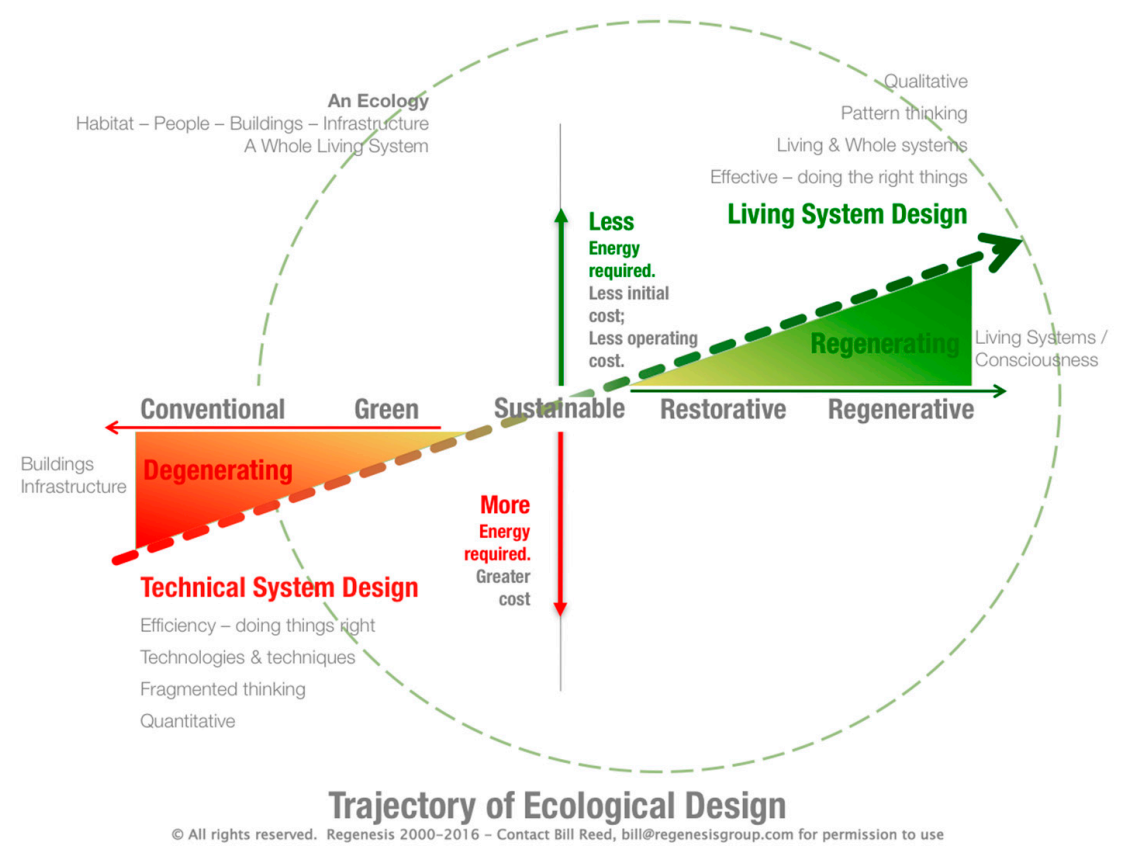

Figure 1. System design continuum—from conventional to sustainable to regenerative systems [39].

This continuum has also been articulated by Russell [40], who proposes "thrivability" as the desired goal, and Shaw, who suggests an alternative discourse to merely surviving, when he proposes that resilience be viewed as a "dynamic process of 'bouncing forward' which provides for the adaptation and constant reinvention needed to innovate and to do new things" [41] (p. 309). Taleb [42] similarly articulates the concept of antifragility; in essence, thriving in the face of shocks and challenges. With a focus on building transformative capacity in individuals and organisations, this paper intends to 
support the flourishing of these expressions at the "regenerative" end of the continuum-regenerative design, thrivability, bouncing forward, anti-fragility.

Turning to the climate change adaptation field, there is growing acceptance that transformational adaptation is necessary to enable system change rather than just relying on incremental adaptation that avoids local disruptions to climate risk [34,42]. Transformational adaptation has been proposed as a necessity to deal with severe climate risk across scales and large vulnerability in certain systems [43]. Although transformational adaptation can accommodate large-scale change, Pelling argues that it does not sufficiently contest the dominant power asymmetries [44]. O'Brien presents the concept of deliberate transformation as consciously creating alternative futures that include ethics, values, and sustainability explicitly [34]. This paper supports and builds on this concept of deliberate transformation. We argue that contesting current systems, which favour elites and undermine environmental, social, and economic sustainability, is necessary, particularly in the context of the global South where social and environmental injustice is prevalent.

Deliberate transformation needs to disrupt the current and dominant power asymmetries that undermine the potential for ethical, ecologically sustainable and well-adapted societies [31,34,45]. This requires that communities have a robust grasp of current political economies, both at a local and global level. It also requires communities to be able to envision various futures and clearly articulate what they are hoping to transform towards.

In order to move from adaptation to deliberate transformation, capacity is needed. Since transformation is non-linear and does not have an end point, it is critical that actors within the system have the capacity to constantly be engaged in and shape the transformation process [33]. Previous work on building and assessing adaptive capacity is useful but insufficient given the demands of transformation [46]. This paper addresses this gap by presenting a few foundations of transformative capacity.

Much adaptive capacity research has looked at individuals directly impacted by climate risks in sectors such as agriculture, fisheries, or water [47-51]. This informative work has shown the many ways to assess adaptive capacity, both through quantitative and qualitative measures. There is less work assessing the adaptive capacity of individuals exposed to a broader range of both direct and indirect climate and development risks. Eakin et al. [52] highlight the importance of investing in two types of capacity to adapt to global change; generic capacity, which helps to meet fundamental human development goals (i.e., education levels or participation in social organisations) and specific capacity, which manages and reduces specific climate threats (i.e., shifts in agricultural practice or access to climate information). Due to a focus on reducing climate impacts, more attention has been paid in climate adaptation work to building specific capacity. If transformation is the goal, it is important that there is a balance between specific and generic capacity [53].

Olsson et al. [54] introduced the term "transformative capacity" in 2010 as the capacity to transform social-ecological systems' trajectories toward ecosystem stewardship at the landscape scale. We argue that building transformative capacity requires a focus on socio-ecological systems as well as individual and collective wellbeing. Simultaneously working with both of these concepts is frequently missing in the literature [54].

Adaptive capacity research has placed limited emphasis on the subjective dimensions of the social world $[55,56]$. Tschakert and St Clair call for radical deliberate transformation that "foregrounds relationships between attitudes, values, and individual and collective transformative action" [45] (p. 318). By its nature this requires a focus on people and their internal subjective dimensions. In addition, in order to achieve transformation new possibilities need to be envisaged which requires the capacity for creativity and exploration of possible futures. The social conception of wellbeing emphasises the importance of looking at subjective, relational, and material dimensions, both now and in the future [55,57]. People's perceptions of what is worth achieving is starting to find more traction as the importance of values, attitudes, care, and agency are prioritised [27,34,58,59]. These wellbeing concepts are increasingly seen as being important for building individual transformative capacity and contributing to social sustainability [60]. 


\section{Some Foundational Aspects of Transformative Capacity}

Participatory planning and design, along with knowledge co-production, is increasingly valued as being vital to achieving both social justice and sustainability [61-63]. Top-down, command-and-control solutions and management remain the dominant practice in settlement making and sustaining, despite acknowledgement that they may be/are out of kilter with the complex, adaptive, dynamical, and non-linear systems we know ourselves to inhabit. As such, the practices to build transformative capacity that we propose are viewed as contributing to a conceptualisation of human society and evolution that is deeply participatory and co-creative, and where each human being is viewed as a creative agent of change in their own right.

We propose, as shown in Figure 2, and set out in the introduction, there are at least three aspects that one needs to focus on, irrespective of context, to cultivate transformative capacity: (1) an awareness of and a re-connection to life support systems; (2) a well-developed sense of agency; and (3) social cohesion. Whilst not intended to be a comprehensive list, we view these as key. They are also mutually reinforcing. If any of these are missing, not well balanced, or are presenting in a pathological fashion, then the capacity to effect deliberate transformation may be stunted. An awareness of, and a re-connection to, life support systems provides the bedrock of the interdependent qualities of agency and social cohesion. As one's awareness grows of the fragility of humanity's life support systems as well as a sense of awe of both earth's and human systems' remarkable ingenuity, diversity and tenacity, so too does the desire to effect change and create alternative pathways. This desire would rapidly fade without well-developed agency in place. In order to actually do the change, strong social bonds are needed at a collective level to achieve any kind of enduring and meaningful impact [64,65] and to change cultural habits and values [33].

Building on this understanding of interlinkages between agency and social cohesion, a healthy expression requires that these qualities be in dynamic relationship. Overexpression of one leads to the silencing of the other. Too much agency can lead to oppression as well as an extreme sense of isolation. Too much relatedness can lead to an incapacity to act, an inertia, and an utter sense of dependence on others. As neuroscientist Rock's limbic brain research shows, a requisite sense of both autonomy (agency) and relatedness (social cohesion) are two of five domains that are fundamental to our experience of being human, pre-dating the emergence of the neo-cortex 50,000 years ago [66]. He demonstrates how our neo-cortex (rational mind) short circuits when our sense of autonomy and our sense of relatedness are undermined and threatened, defaulting to our reactive limbic brain. Reactive, impulsive, often violent and harmful behaviours stemming from these ancient brain structures are not conducive to effective and impactful stewardship of deliberate transformation.

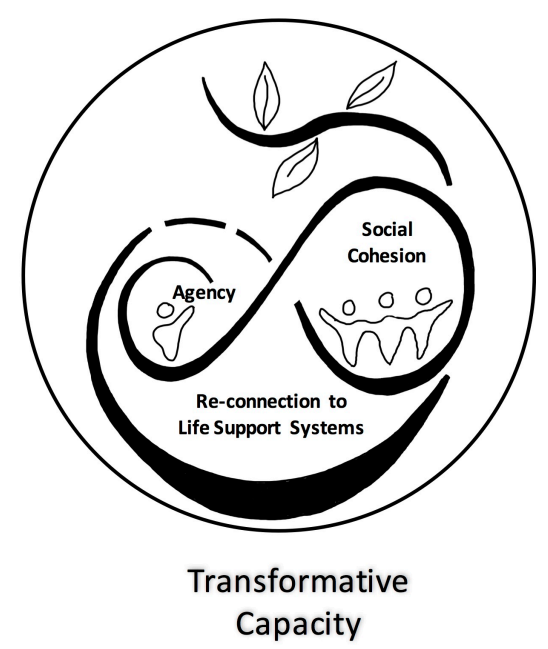

Figure 2. Domains of transformative capacity: agency, social cohesion, and re-connection to life support systems. 


\subsection{Re-Connection to Life Support Systems_From "dominion over" to Collaborative Co-Creation}

As humanity urbanises, our societal understanding of the myriad systems that support life become more and more tenuous. Water comes from a tap, our food from a supermarket, our waste gets flushed down the toilet or thrown into a rubbish truck, energy is available at the flick of a switch. Whilst these "dignities of modernity" [23] (p. 69). have utterly transformed the human experience of life from being what Hobbes in Leviathan described as "solitary, poor, nasty, brutish and short", it has become clear that they come with a devastating ecological impact, as well as being extremely brittle and unable to cope with shocks [67] (p. 96). Critically, much of humanity still does not enjoy the convenience and easy access to the basic life supporting services that many urban dwellers take for granted. Given that most of the rapid urbanisation in Africa (projected to reach a total urban population of 1.2 billion people by 2050) will include vast urban slum settlements (with fewer than 0.5 million people per settlement lacking basic services) [9], re-connecting to what sustains life becomes a survival imperative. This is both an intangible, even "spiritual" reconnection-a sense of awe, wonder, and reverence towards the living systems that comprise planet Earth—as well as the kind of re-connection that talks to self-sufficiency and resilience in an extremely practical manner.

At the core to this re-connecting is the move from a "dominion over" world view that views the earth as a resource to exploit for humanity's exclusive benefit, towards a world view that views each human being as a creative participant in an ever-unfolding co-production with all sentient life and the Earth systems that nourish us.

Practices that would develop awareness and re-connection commence with the simple, yet profound, act of making these systems visible, building on Kegan's subject-object theory. This includes seeing what is "out there", as well as bringing into awareness the degrees to which we are not separate from the systems that support us. Scharmer [68] calls this the moment of turning the light back on yourself, and to him, this is a key transformative moment, pregnant with possibility, as individual actors grasp their complicity as well as their agency to effect real change. Harari suggests that it is our uniquely human capacity to "weave common myths ... (which gives Homo) Sapiens the unprecedented ability to cooperate flexibly in large numbers"[69] (p. 27). Storytelling in all its forms - oral traditions, mapping, movie-making - is at the heart of these practices of making systems visible-telling stories of "what is" (Where does our water come from? Where does it go? How does nature clean water?) in order to co-create new narratives of "what could be?".

We propose that supporting communities to see the human-made systems they are currently embedded in, to understand the full dimensions of their dependencies as well as the damage caused to both ecosystem function and human dignity and equality, is a critical foundation to building transformative capacity [70]. This new awareness would then support local receptivity to more ecologically-sound life support system design solutions. For instance, and particularly in the global South, strategies that may easily be construed of as being anti-progress, like creating human-engineered wetland systems to manage storm water drainage, as opposed to the current practice of linear, ecologically-destructive concrete channels, would then have a greater chance of traction, of landing on more fertile soil [71].

\subsection{Agency and Creativity}

The second aspect that we propose as a key to building transformative capacity, is healthy human agency. Here we include a sense of independence, self-reliance, and self-sufficiency and acknowledging the uniqueness of each human being [72]. Examining how and where human autonomy and agency express in pathological ways in society provides a sense of the terrain that reveals why nurturing a healthy expression of this quality is a key dimension of transformative capacity.

Expressions of pathology range from abuse of power and "power over"—elegantly described by Martin Luther King who said that "power without love is reckless and abusive and love without power is sentimental and anaemic" - through to ennui and apathy, and beyond, to crippling despair [73]. This is not the necessary grieving that arises when one faces the imminent reality of planetary and societal collapse, but more a despair that renders one impotent [74]. The absence of healthy autonomy 
and agency also expresses as a sense of entitlement, coupled with a victim mentality and leads to passive consumers of governments' and businesses' goods and services, as opposed to an engaged, creative and contributing citizenry. The reification of the individual over the collective, the cult of the individual that permeates and underpins our current consumption-fuelled global economy, is perhaps one of the more intractable dimensions of unhealthy human agency. In dynamic concert with agency's corollary, a pervasive dependency at all scales-dependence on hand-outs, dependence on fossil fuels, dependence on globalised, brittle supply chains, on financial aid, on external expertise-we get to the heart of what needs to change, to transform.

In our reading, agency is a close companion of innovation and creativity, and as such, is not only core to being human, but also core to evolutionary emergence, across all domains, from atoms to ideas [75]. We can be active co-creators of our future, not just passive victims of human-made and natural systems far more powerful than ourselves. Active citizenry is at the heart of this.

Building self-awareness and self-knowledge is an important dimension of developing personal agency, engendered through self-reflection, self-compassion, and introspection. Similarly, personal agency is built through engaging in tasks that require working through from a conceptual idea through to a completed product, providing an antidote to the increasing specialisation that characterises contemporary culture. The more traditional leadership development skills, like public speaking, setting up meetings and interviews with strangers, enrolling others to support something one is passionate about—all these contribute to developing human agency.

\subsection{Growing Community, Strengthening Social Cohesion}

The third aspect that we propose as a key to building transformative capacity, is a strong sense of social cohesion. Here we include ideas of human communion at all scales: bonds, community ties, wider social networks.

Modernity and urbanisation are often accompanied by the fracturing of the kind of robust social networks more characteristic of small towns and rural areas, of pre-industrial society [76]. This is not to reify or romanticise a golden past, because there was no such thing, but rather to acknowledge the alienating potential of contemporary urban life. In times of extreme crisis the odds are stacked in favour of those with strong social networks. Knowing and trusting ones' neighbour is as much a survival imperative as re-connecting to the Earth systems that sustain life. At the core, we are social animals, unable to thrive alone. Having access to social networks of reciprocity and trust increase wellbeing [77].

One of the more palpable practices that build social cohesion is the process of humans organising themselves to create something together, to learn something new together, to struggle and overcome adversity together. Hamdi suggests this as an enduring and simple definition of healthy human development: "Development ... happens when people, however poor in money, get together, get organised, become sophisticated and go to scale.... Development ... is that stage when you are secure enough in yourself, individually or collectively, to become interdependent; when ' $I$ ' can emerge as 'we', and also when 'we' is inclusive of 'them'" [78] (p. xv/xvi).

\section{Transdisciplinary Research in the Bergrivier Municipality in South Africa}

This paper draws on work from the Fostering Local Wellbeing (FLOW) programme that was funded through the Technical and Management Support (TMS) Programme (managed by the South African National Treasury), which is part of the Development Cooperation Agenda between the governments of South Africa and Belgian Flanders [13]. The programme started in September 2014 and closed in August 2016. FLOW aims to contribute towards fostering wellbeing in communities around South Africa through developing adaptive and transformative capacity in the face of climate change, increasing economic inequality and high rates of unemployment, particularly among the youth. It aims to do this through a transdisciplinary approach of interlinked activities and programmes, at the heart of which is a youth leadership development initiative-the FLOW Ambassador Programme, coupled with the introduction of a community currency. 
This paper focuses on one of the two project sites where FLOW was based; that of the Bergrivier Municipality (BM), situated in the West Coast District of the Western Cape Province and home to 62,000 people, as illustrated in Figure 3. The municipality covers a geographic area of approximately $4407 \mathrm{~km}^{2}$ and includes nine urban settlements, approximately $40 \mathrm{~km}$ of coastline and a vast rural area. The project took place in Piketberg, which is the administrative seat and Goedverwacht, a nearby agricultural settlement.

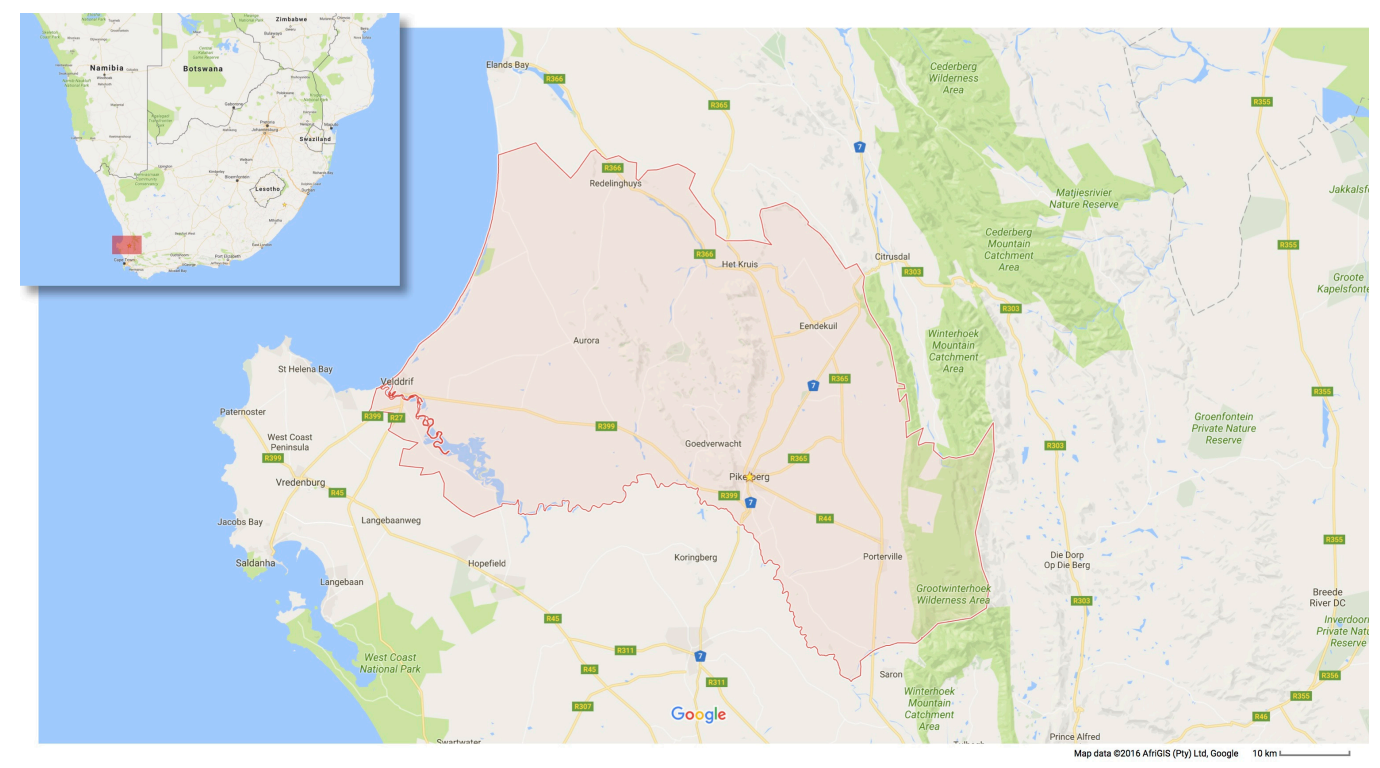

Figure 3. Map of Bergrivier Municipality boundary, Western Cape, South Africa (shown by red line) [79].

Poverty is a challenge that all municipalities in South Africa have to deal with, and Bergrivier is no exception, with $25.2 \%$ of the total number of households registered as indigent and increasing annually (indigent households are defined as households where the combined monthly income of the household is less than the equivalent of two state pensions plus $10 \%$ ). The municipality's dominant employment sector is agriculture, including livestock as well as grain and fruit farming, but jobs in this sector declined rapidly between 2000 and 2010 [80].

Small towns are where many people settle, given rural decline and in-migration [7]. As Nel highlights, "some of the most profound development challenges are being faced and fought in the innumerable smaller centres" [81] (p. 253). This research addresses this gap, where small towns are often forgotten, in lieu of cities, yet given the multitude of small towns, their transformation could have a significant impact [10].

This research in the Bergrivier municipality builds on a history of transdisciplinary work in the region that started in 2012, when University of Cape Town (UCT) academics helped co-produce the Bergrivier Municipality Climate Adaptation Plan [61] and convened a Climate Knowledge network, in which a group of 20 UCT academics and practitioners from the Bergrivier region co-explored questions and potential responses to climate and development. Although engagement in the region started around climate change adaptation, it became clear that the range of social, economic, and ecological stresses require a more holistic response. Although elements regarding the specific capacity of climate stress response were included in the project, the focus was on strengthening the generic capacity to respond to multiple stressors and build transformative capacity to actively shape a future of choice [52].

Engagement with the complex nature of the Bergrivier context led to a growing awareness that it would be most effective to work systemically-interacting simultaneously with multiple and layered project entry points, across actor groups and scales. Figure 4 illustrates the three actor groups 
that the programme engaged with-youth, local government, and local business. Whilst building transformative capacity amongst youth served as the primary and generative entry point, the youths' intersection with both local government, local business and civil society more broadly was envisaged as being mutually reinforcing in building transformative capacity across all three actor groups.

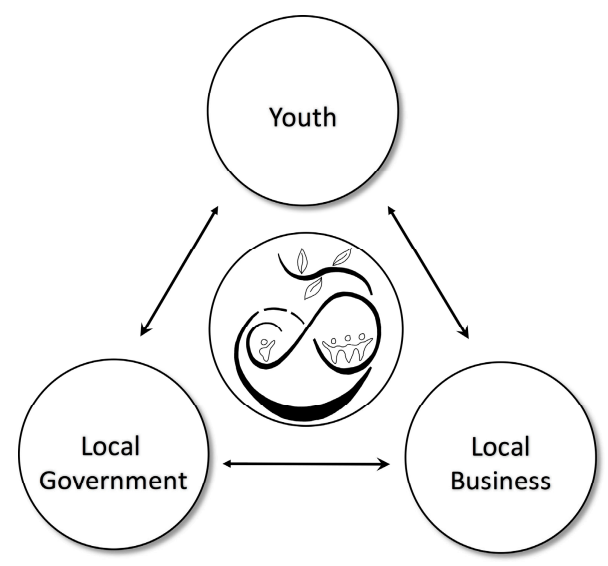

Figure 4. The three central actor groups of FLOW engagement.

The FLOW programme took an inductive action research approach to produce knowledge by creating, revisiting and intervening in concrete social practices with a team of academics, practitioners, government officials, business representatives, and civil society. This aligns with engaged scholarship and transdisciplinary thinking, where those within the academy partner with those outside the academy to find answers to pressing social, civic, and economic problems [82]. The transdisciplinary approach that was adopted drew on different theoretical approaches, required because of the complex nature of the problem $[34,35,56]$. This involved the continued co-operation of a diverse team in designing the research and its approach: The disciplines and grounded skills that were drawn on included behavioural economics, geography, vulnerability and adaptation to climate change, architecture, sustainable urbanism, participatory development, engineering, information and communications technology (ICT), entrepreneurship, organisation and governance design, agronomy, permaculture, community currency expertise, communication and user-experience design, process design, and facilitation.

The project team invested time at the project inception developing an understanding of what transdisciplinarity meant to each participant and then developed a shared understanding and definitional framework. This was essential, given the various and at times conflicting ways in which the term is used in both academia and practice. It was agreed that the kind of transdisciplinarity we were interested in includes the understanding of a research approach that integrates academic and practitioner knowledge [83], whilst also leaning towards transdisciplinary approaches that embrace the unity of knowledge and unimagined possibilities as advocated by Nicolescu in his Manifesto of Transdisciplinarity [84] and the importance of cognitive development and group competencies as articulated by Stein [85].

Transformative capacity needs to be measured by both "interior validity claims (e.g., asking how one feels)" and "exterior validity claims (e.g., measuring what one does)", which requires a diversity of methods [86] (pp. 92-93). Methods included a baseline survey with small businesses, as well as qualitative data collected through interviews and journaling questions that the FLOW ambassadors shared throughout the project. All three authors have been involved in frequent visits to the area (at least monthly). This approach of working with the various actors, including the ambassadors, business partners, and local coordinators to understand how they feel about the changes and what they have achieved, has been the core of our project. The survey data and qualitative data helped to reflect on implementation and what might change, meeting the needs of engaged scholarship and practice. 
Building on a shared view of what underpins meaningful transdisciplinary research, the project team developed a suite of principles to guide the project implementation. These include: (1) infusing and embedding systems thinking across the project, from strategic programme design through to operational minutiae; (2) making visible and explicit relevant relationships, artefacts, and systems that are generally invisible or not deemed important, whilst maintaining a sense of mystery and not-knowing; (3) employing an "appreciative inquiry" approach, i.e., always seeking out what's working, and building up from that; (4) learning by doing, working with prototypes in tight feedback loops and in an iterative fashion, trusting that it is "safe to fail;" (5) co-producing and co-creating at all levels and with all actors of the project, designing and learning in a participatory manner every step of the way; and (6) actively engaging each project participant, as well as each person the project intersects with as a "whole person" with unique gifts, histories, emotions, meaning-making capacities, and challenges, ensuring that there is time and space allowed for working with the less tangible, yet essential, dimensions of being human.

\section{Building Transformative Capacity on the Ground: The FLOW Ambassador Programme}

Like much of the so-called developing world, South Africa is variously blessed or cursed with a "youth bulge", depending on one's perspective. "According to the World Bank, 200 million people in Africa fall into the youth (15-24 years old) category, making up 20 percent of the population, 40 percent of the workforce, and 60 percent of the unemployed on the continent" [87] (p. 9). Should the current trends of rising youth unemployment continue, then an increasingly urbanised and educated youth have the potential to contribute to rising instability in already uncertain times. As such, the FLOW project has youth development at its core, viewing the work with youth at risk as one of the more effective entry points for sustainable and deliberate transformation.

The FLOW Ambassador Programme in the Bergrivier region has gone through two iterations over the two-year project cycle with two cohorts of FLOW Ambassadors (FAs). The first iteration took place from September 2014-December 2015 and comprised two sub-phases, a nine-month foundation phase and a six-month consolidation phase. The second iteration (with a new cohort of FAs) comprised a three-month programme that ended in June 2016. Each FA programme had an underpinning theme or series of themes related to foundations of local wellbeing - local exchange, water, energy, food, land, shelter and building materials, health, and so on. The first iteration in the Bergrivier region worked with eight local youth from two towns and focused on local exchange and the water system, linked to the intention of launching a complementary, mutual-credit design, community currency. The second iteration worked with nine youth, from three towns and focused on energy. The three central aspects of transformative capacity were each developed through a series of interlinked activities that unfolded through the project implementation.

During the first four months of the first iteration of the programme, the FAs focused on making visible economic activity in their towns and villages, as well as beginning to understand the resource flows through their homes, neighbourhoods, and towns. They mapped economic activity (both formal and informal) on mobile phones as well as digital and paper maps. They visited landfill sites and recycling depots, made diagrams of how energy, water, and waste flowed through their houses and built scale models of their own homes out of cardboard. They looked at their town through one another's eyes, sharing the places they love the most, and found themselves surprised. They were introduced to big picture concepts and ideas, like climate change and resource depletion, and watched relevant documentaries. They quickly made themselves at home with cutting-edge digital technology_-for many a new, and even daunting, experience.

Personal and leadership development skills included co-creating their own training contracts with the FLOW project facilitators, workshopping reciprocal expectations, conflict resolution, defining underperformance disincentives, and reward incentives, set up a rotating team leadership roster, and developing a shared practice of daily check-ins and check-outs at the beginning and end of each day. This helped to embed learning, reflection and iterative planning into the rhythms of each 
day, as well as being a focused time for personal victories and constraints to be expressed. They also each kept a daily private journal after the morning check-in, responding to questions that they had taken home the night before: "Who in your town inspires you, and why?", "What kind of town do you want to live in some day?", etc. Three months into the programme, they took part in a five-day training programme in mobile journalism, where they were taught the basics in the art of storytelling using short documentaries shot on mobile phones and edited on desktop computers in the project office as the primary medium. Here they were trained to build their individual skills from coming up with an idea, story-boarding, scheduling the shoot, filming, editing, doing voice-overs and sub-titles, and finally uploading to YouTube. This is distinct from more conventional video journalism training where each of these are taught as separate skills, as the intent here is to build individual agency as an all-in-one mobile journalist (MoJo), as well as the capacity to work in a team. They then honed their skills by producing two-minute documentaries showcasing local businesses in the Bergrivier region as a key input into making visible local exchange and as a foundation piece to the introduction of a business-to-business, mutual credit-type community currency.

After a short holiday, the FAs dived into an intense five-month period of simultaneously conducting a sixty-six question baseline survey with 450 local businesses as well as supporting the launch of the Bergrivier community currency (BRAND), complementary to South Africa's national currency, the Rand. The survey focused on small businesses in the region and was conducted in Piketberg and Goedverwacht, as well as in the town of Velddrif, which served as a control. The survey was set up on the project mobile phones, and the FAs quickly became adept at navigating the complexities of surveying for research purposes: cold-calling, planning ahead, logistic challenges, handling rejection and disappointment. Survey respondents were incentivised to participate through enrolment in a series of lucky draws that took place at five community currency information and enrolment events. Here, the FA-made two-minute documentaries were presented, along with community currency interactive simulations and informative power point presentations. The BRAND was officially launched on 30 May 2015, with the FAs facilitating most of the small business enrolment through one-on-one dialogues in peoples' homes, as well as much of the launch planning and logistics, at all times supported by the Bergrivier Local Co-ordinator, a Goedverwacht based farmer-entrepreneur, and the FLOW project team. The BRAND launch marked the end of the foundation phase of the FA programme.

The consolidation phase of the first FA programme spanned from June to December 2015, and focused largely on monitoring the use of the BRAND, and exploring various design iterations to increase its acceptance. At the same time, the FAs began to focus on the water system; coming to grips with the natural system through site visits to the catchment mountain source, as well as to the river estuary. They also mapped and made movies of the municipal water system, from the point of extraction from the Berg River, through the filtration plant, to the storage dams, through their own homes, and to the storm water systems and sewer works. They conducted audits of their own water use at home, and continued to both watch and write about relevant documentaries on a weekly basis. The personal journaling process continued in contained bursts, and culminated in a day-long workshop where each FA was coached to crystalize their unique skills and potential, and articulate the kind of work they wish to contribute towards a more equitable and sustainable future.

Whilst the project was mostly funded by the Flemish Government through the South African Treasury along with co-funding from Meshfield, the project conceptualisers and implementers, the FA's stipends were funded by the Bergrivier Municipality, who also provided support with T-shirts, printing, transport, catering and venues. Regular planning meetings took place between the FLOW project team and Bergrivier Municipality officials, where mutually beneficial activities were initiated and co-developed. The FAs were integrated into the formal life of the municipality, being introduced to the local councillors in the Council Chamber and encouraged to share their experiences and speak in public. They made short documentaries about the life supporting systems of municipal infrastructure that were screened at Integrated Development Planning (IDP) public meetings, and they were celebrated in a very moving graduation ceremony that was both designed and hosted by the Municipal Manager in the Council Chambers. 


\section{Reflecting on Building Transformative Capacity}

In order to comment on how the FLOW programme started to build transformative capacity, this section reflects briefly on how the FLOW Ambassador programme engaged with other actor groups, and in doing so built their own and others' transformative capacity. As shown in Figure 5, building transformation is supported by moving towards the desired goal of a partner state, ethical business, and engaged civil society. We start by listing how the activities of the FA programme developed the youth's agency, their social cohesion, and their reconnection to life support systems in Table 1 below, before looking at how the FA activities strengthened engagement with the three actor groups across the three aspects of transformative capacity.

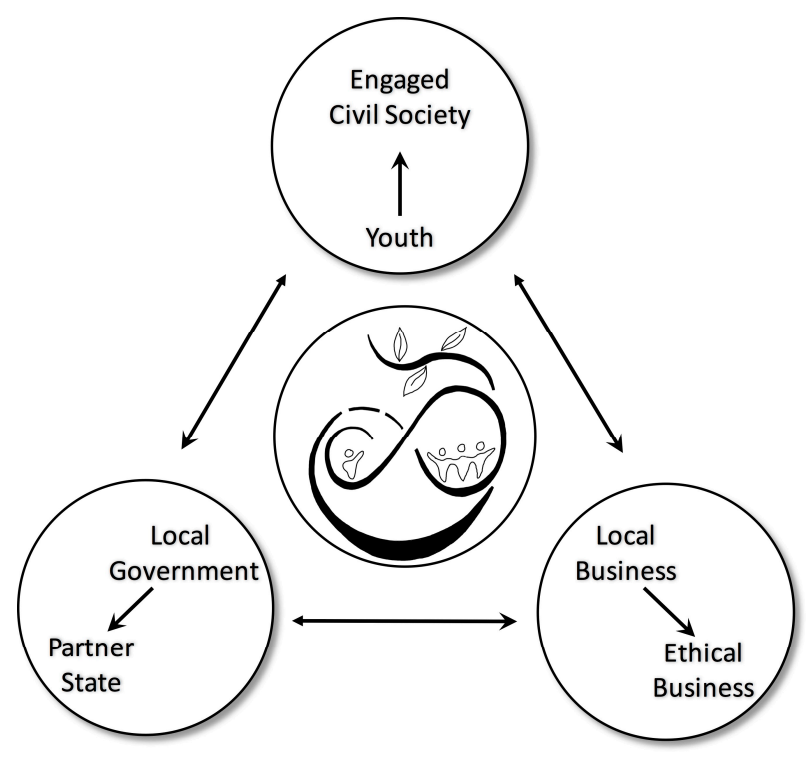

Figure 5. Deliberate transformation: Building the transformative capacity of the three mutually-reinforcing actor groups towards desirable futures.

Although some of the activities of the FLOW ambassadors were narrated above, it is useful to map out which aspects of transformative capacity the different activities addressed.

Interaction between different actor groups is central to building transformative capacity across a system. We argue that through the engagement with and activities of the FAs, transformative capacity has started to be developed in the local government, local business and broader civil society.

For local government, transformative capacity started to be developed in many ways. Through mapping the municipal water and sewage systems, that were presented back to wider community members in local government forums, the FAs communicated to broader civil society how local government provides essential services to its citizens, as well as showing where infrastructure spending is being channelled to, and highlighting potential places of partnership in maintaining and developing co-created alternatives (such as bioswales, recycling programs, etc.). The mapping of local businesses and the introduction of the community currency opened up possibilities for local government to leverage the "multiplier effect" of community currencies to pay for social services (such as litter collection and gardening), as well as identifying opportunities to support local economic activity. The model-building, mapping, movie-making, and community currency all form foundational tools for bottom-up citizen participatory planning processes with local government. The direct inclusion of the youth voice in municipal meetings further builds the citizens' understanding of municipal processes and provides a platform for the youth to become more politically active and engaged citizens. 
Table 1. Contribution of FLOW ambassadors' activities to the reconnection to life-support systems, agency, and social cohesion.

\begin{tabular}{|c|c|c|c|}
\hline Youth-FLOW Ambassador Activities & Agency & $\begin{array}{l}\text { Social } \\
\text { Cohesion }\end{array}$ & $\begin{array}{l}\text { Reconnection to } \\
\text { Life-Support Systems }\end{array}$ \\
\hline Making visible economic activity & & $\mathrm{x}$ & $\mathrm{x}$ \\
\hline $\begin{array}{l}\text { Mapped economic activity } \\
\text { (mobile phones, digital and paper maps) }\end{array}$ & & & $\mathrm{x}$ \\
\hline Understanding resource flows & & & $\mathrm{x}$ \\
\hline Visited landfill sites and recycling depots & & & $\mathrm{x}$ \\
\hline Diagrams of energy, water, waste flows through their homes & & & $\mathrm{x}$ \\
\hline Built scale models of their homes out of cardboard & & & $\mathrm{x}$ \\
\hline Saw their town through each other's eyes & & $\mathrm{x}$ & $\mathrm{x}$ \\
\hline Co-created their agreements with the project & $\mathrm{x}$ & $\mathrm{x}$ & \\
\hline $\begin{array}{l}\text { Introduced to ideas such as climate change and } \\
\text { resource depletion }\end{array}$ & & & $\mathrm{x}$ \\
\hline Learnt how to work with internet-based collaboration tools & $\mathrm{x}$ & & \\
\hline Developed weekly rotating leadership roster & $\mathrm{x}$ & & \\
\hline Developed weekly meeting practices & & $\mathrm{x}$ & \\
\hline $\begin{array}{l}\text { Developed learning and reflection practices by embedding } \\
\text { check-ins and check-outs, as well as daily journaling } \\
\text { exercises into their days }\end{array}$ & $\mathrm{x}$ & $\mathrm{x}$ & \\
\hline $\begin{array}{l}\text { Learnt Mobile Journalism (MoJo) skills—scripting, } \\
\text { interviewing, shooting, editing using mobile phones }\end{array}$ & $\mathrm{x}$ & & \\
\hline $\begin{array}{l}\text { Created over one hundred } 30 \mathrm{~s} \text { - to } 2 \text { min-documentaries } \\
\text { showcasing local formal and informal businesses }\end{array}$ & $\mathrm{x}$ & $\mathrm{x}$ & \\
\hline $\begin{array}{l}\text { Learnt surveying skills for research purposes } \\
\text { (cold-calling, planning ahead, logistic arrangements, } \\
\text { handling rejection and disappointment) }\end{array}$ & $\mathrm{x}$ & & \\
\hline $\begin{array}{l}\text { Completed a } 66 \text { question-research survey with } \\
450 \text { businesses, using mobile phones as collection devices }\end{array}$ & $\mathrm{x}$ & $\mathrm{x}$ & \\
\hline $\begin{array}{l}\text { Organized community currency evenings to educate } \\
\text { potential small businesses about money and community } \\
\text { currencies, enrol potential small businesses as participants, } \\
\text { and showcase the } 30 \text { s-business movies they had made }\end{array}$ & $\mathrm{x}$ & $\mathrm{x}$ & $x$ \\
\hline $\begin{array}{l}\text { Enrolled potential community currency network members } \\
\text { through one-on-one dialogues at their businesses/homes }\end{array}$ & $\mathrm{x}$ & & \\
\hline $\begin{array}{l}\text { Planning and arranging the logistics of the community } \\
\text { currency BRAND launch }\end{array}$ & $\mathrm{x}$ & & \\
\hline Launching the community currency BRAND & $\mathrm{x}$ & $\mathrm{x}$ & \\
\hline $\begin{array}{l}\text { Learning about the natural water system } \\
\text { (from the mountain source to the river estuary) }\end{array}$ & & & $\mathrm{x}$ \\
\hline $\begin{array}{l}\text { Learning about the municipal water system } \\
\text { (extraction from river, filtration, storage in dams, } \\
\text { piping to homes) }\end{array}$ & & & $\mathrm{x}$ \\
\hline $\begin{array}{l}\text { Learning about treatment of wastewater (effluent from } \\
\text { homes, sewerage works, stormwater systems) }\end{array}$ & & & $\mathrm{x}$ \\
\hline Conducted audits of water use at home & & & $\mathrm{x}$ \\
\hline $\begin{array}{l}\text { Created a summary water system presentation, } \\
\text { including short movies that was made available online and } \\
\text { presented back to municipal officials }\end{array}$ & & $\mathrm{x}$ & $\mathrm{x}$ \\
\hline $\begin{array}{l}\text { Ambassadors introduced to the municipal officials, } \\
\text { local counsellors and international funders }\end{array}$ & $\mathrm{x}$ & & \\
\hline $\begin{array}{l}\text { Presented and participated in municipal Integrated } \\
\text { Development Planning (IDP) meetings }\end{array}$ & $\mathrm{x}$ & $\mathrm{x}$ & $\mathrm{x}$ \\
\hline
\end{tabular}


For local business, the mapping of local economic activity, the shooting of documentaries about local business and the introduction of the community currency increases the potential for local trade through making local wants and needs more visible, all contributing to building transformative capacity. Further, the mapping of local economic activity supports local businesses to see opportunities to grow more localised trade. The mapping of the municipal systems, as well as the identification of potential alternatives to make the current life support systems more resilient (such as rain-water harvesting tanks, Solar PV, bioswales, etc.) assist local businesses to develop new possible business opportunities. The community currency increases the liquidity in the local market and enables local businesses to exchange their capacities.

For civil society, the following activities have contributed to building transformative capacity; the mapping, movie-making, and story-telling has increased civil society's appreciation of the town of the town that they live in, the diversity of the community that surrounds them, and the socio-ecological systems that support them. Through the water, waste, sewage, and energy mapping and presentations, civil society has improved their understanding of the need to develop alternatives in order to increase local resilience. The introduction of the community currency has highlighted the importance of localisation and has the potential to encourage greater demand for local food production and more localised supply chains. The mapping of the region's economic activity in the form of a directory of local goods and services has allowed civil society to more actively support local economic activities. The model-building, mapping, movie-making, and community currency all form foundational tools for citizens to engage with each other in participatory planning processes and explore shared resource and economic opportunities.

\section{Conclusions}

In addition to drawing on the rich literature and practice of climate change adaptation, this paper builds on the concepts of urban sustainability and urban resilience. These are seen as being on a continuum that tilts towards thrivability and regenerative design as the goal of transformation. Building the capacity of both individuals and collectives to effect deliberate transformation towards shared local understandings of context responsive and culturally-resonant futures contributes to building both urban sustainability and resilience, as well as transcending the paradoxical dimension inherent in these practices.

To build transformative capacity we need to nurture three mutually reinforcing domains that we see as fundamental (but not exhaustive): (1) reconnection to life-support systems; (2) social cohesion; and (3) agency. Reconnection is strengthened when we start to make visible the resources that support our daily lives. Once we are more conscious of these links, we can become creative participants in the interaction with and shaping of our systems. Social cohesion demands deepening our connection to others, in our own circles, and in circles beyond our normal networks. As individuals, we need to be active citizens that exhibit agency. This requires creativity to make visible, be self-reflexive, and see our connection to others and the resources that support us.

In urban settlements, where people are converging rapidly, resources are becoming more stressed, settlements are degrading, and people are often disconnected and feel powerless, a new way of imagining and being is critical. We need to move from viewing "the city simply as an inventory of resources to be administered by politicians and bureaucratic experts" to viewing "the city's residents as resourceful, imaginative agents in their own right" and "[g]overnment, re-imagined as a hosting infrastructure for countless self-organised commons" [88]. To do this, city-making will require transformative capacity across civil society, local government, and local business.

In order to build transformative capacity, interdisciplinary and transdisciplinary work is needed. This work is not for individuals acting in isolation; it is about developing a commons where diverse knowledge and input is celebrated. As seen with the FLOW programme, academics, practitioners, citizens, local business, and local government can all contribute to conceptualisation and implementation of a project. When this happened in the FLOW programme, the support from 
citizens, local business and local government was evident and contributed to both policy and practice. FLOW was integrated into three local government policy documents and effected many changes, as described above. Lasting change, or transformation, requires the most difficult work of all, shifting deeply-ingrained cultural habits and values [32]. This cannot be done by individuals acting alone; it requires social action powered by networks of trust, and human beings intimately connected to the systems that support all sentient life.

Acknowledgments: The FLOW programme was funded by South African National Treasury through the Flemish Government. The authors would like to acknowledge the range of inputs and support received from a variety of people during the project, including the FLOW team, the FLOW ambassadors, the Bergrivier Municipality and the African Climate and Development Initiative at the University of Cape Town (UCT). We would like to thank Chrisna Du Plessis and the second, anonymous reviewer for their valuable input.

Author Contributions: Gina Ziervogel, Anna Cowen and John Ziniades conceptualised the manuscript collaboratively. All three wrote sections of the paper and all three worked on editing the paper. All authors have read and approved the final manuscript.

Conflicts of Interest: The authors declare no conflicts of interest.

\section{References}

1. United Nations Framework Convention on Climate Change. Paris Agreement. 21st Conference of the Parties; Secretary-General of the United Nations: New York, NY, USA, 2015; pp. 1-25.

2. Welsh, M. Resilience and responsibility: Governing uncertainty in a complex world. Geogr. J. 2014, 180, 15-26. [CrossRef]

3. Gillard, R.; Gouldson, A.; Paavola, J.; Van Alstine, J. Transformational responses to climate change: Beyond a systems perspective of social change in mitigation and adaptation. Wiley Interdiscip. Rev. Clim. Chang. 2016, 7, 251-265. [CrossRef]

4. Bahadur, A.; Tanner, T. Transformational resilience thinking: Putting people, power and politics at the heart of urban climate resilience. Environ. Urban. 2014, 26, 1-15. [CrossRef]

5. Revi, A.; Satterthwaite, D.; Aragon-Durand, F.; Corfee-Morlot, J.; Kiunsi, R.B.; Pelling, M.; Roberts, D.; Solecki, W.; Gajjar, S.P.; Sverdlik, A. Towards transformative adaptation in cities: The IPCC's Fifth Assessment. Environ. Urban. 2014, 26, 11-28. [CrossRef]

6. Ahern, J. From fail-safe to safe-to-fail: Sustainability and resilience in the new urban world. Landsc. Urban Plan. 2011, 100, 341-343. [CrossRef]

7. United Nations Human Settlements Programme (UN-HABITAT). The State of African Cities 2008: A Framework for Addressing Urban Challenges in Africa; UN-HABITAT: Nairobi, Kenya, 2008.

8. United Nations Department of Economic and Social Affairs (ESA). World Urbanization Prospects: The 2014 Revision, Highlights; ESA Publications, 2014. Available online: https://esa.un.org/unpd/wup/ Publications/Files/WUP2014-Highlights.pdf (accessed on 29 July 2016).

9. Pieterse, E.; Simone, A. Rogue Urbanism: Emergent African Cities; Jacana Media: Sunnyside, South Africa, 2013.

10. Van Niekerk, J.; Marais, L. Public Policy and Small Towns in Arid South Africa: The Case of Philippolis. Urban Forum 2008, 19, 363-380. [CrossRef]

11. Carmin, J.; Nadkarni, N.; Rhie, C. Progress and Challenges in Urban Climate Adaptation Planning: Results of a Global Survey; Massachusetts Institute of Technology: Cambridge, MA, USA, 2012.

12. Stirling, A. Transformations: Emancipating Transformations: From Controlling "the Transition" to Culturing Plural Radical Progress; STEPS Center: Brighton, UK, 2014.

13. Fostering Local Wellbeing Project (FLOW). Available online: www.flowafrica.org (accessed on 12 August 2016).

14. Edwards, M.G. Organizational Transformation for Sustainability: An Integral Metatheory; Routledge: New York, NY, USA, 2010.

15. Meadows, D.H.; Meadows, D.L.; Randers, J.; Behrens, W.W. The Limits to Growth: A Report for the Club of Rome's Project on the Predicament of Mankind; Universe Books: New York, NY, USA, 1972.

16. Folke, C.; Carpenter, S.; Elmqvist, T.; Gunderson, L.; Holling, C.S.; Walker, B. Resilience and sustainable development: Building adaptive capacity in a world of transformations. Ambio 2002, 31, 437-440. [CrossRef] [PubMed] 
17. McDonough, W.; Braungart, M. Cradle to Cradle: Remaking the Way We Make Things; North Point Press: New York, NY, USA, 2002.

18. Ritchie-Dunham, J. Ecosynomics: The Science of Abundance; Vibrancy Institute: Belchertown, MA, USA, 2014.

19. Eisenstein, C. Sacred Economics: Money, Gift, and Society in the Age of Transition; Evolver Editions: Berkeley, CA, USA, 2011.

20. Lietaer, B.; Arnsperger, C.; Goerner, S.; Brunnhuber, S. Money and Sustainability The Missing Link; Triarchy Press: Devon, UK, 2012.

21. Kostakis, V.; Bauwens, M. Network Society and Future Scenarios for a Collaborative Economy; Springer: Berlin, Germany, 2014.

22. Kegan, R. In Over Our Heads: The Mental Demands of Modern Life; Harvard University Press: Cambridge, MA, USA, 1994.

23. Wilber, K. Integral Psychology; Shambhala: Cambridge, MA, USA, 2000.

24. Loevinger, J. Ego Development: Conceptions and Theories; Jossey-Bass: San Francisco, CA, USA, 1976.

25. Kegan, R. The Evolving Self: Problem and Process in Human Development; Harvard University Press: Cambridge, MA, USA, 1982.

26. Leichenko, R. Climate change and urban resilience. Curr. Opin. Environ. Sustain. 2011, 3, 164-168. [CrossRef]

27. Tschakert, P.; van Oort, B.; St. Clair, A.L.; LaMadrid, A. Inequality and transformation analyses: A complementary lens for addressing vulnerability to climate change. Clim. Dev. 2013, 5, 340-350. [CrossRef]

28. Ernstson, H.; Van Der Leeuw, S.E.; Redman, C.L.; Meffert, D.J.; Davis, G.; Alfsen, C.; Elmqvist, T. Urban transitions: On urban resilience and human-dominated ecosystems. Ambio 2010, 39, 531-545. [CrossRef] [PubMed]

29. Davoudi, S. Resilience: A Bridging Concept or a Dead End? Plan. Theory Pract. 2012, 13, 299-333. [CrossRef]

30. Sellberg, M.M.; Wilkinson, C.; Peterson, G.D. Resilience assessment: A useful approach to navigate urban sustainability challenges. Ecol. Soc. 2015, 20, 43. Available online: http://www.ecologyandsociety.org/ vol20/iss1/art43/ (accessed on 29 July 2016). [CrossRef]

31. Evans, J.P. Resilience, ecology and adaptation in the experimental city. Trans. Inst. Br. Geogr. 2011, 36, 223-237. [CrossRef]

32. Davoudi, S. On Resilience. disP Plan. Rev. 2013, 49, 4-5. [CrossRef]

33. Pelling, M.; O’Brien, K.; Matyas, D. Adaptation and transformation. Clim. Chang. 2014, 133, $113-127$. [CrossRef]

34. O’Brien, K. Global environmental change II: From adaptation to deliberate transformation. Prog. Hum. Geogr. 2012, 36, 667-676. [CrossRef]

35. Rickards, L.; Howden, S.M. Transformational adaptation: Agriculture and climate change. Crop Pasture Sci. 2012, 63, 240-250. [CrossRef]

36. Ellin, N. Integral Urbanism; Routledge: Abingdon, UK, 2006.

37. Meerow, S.; Newell, J.P. Resilience for whom, what, when, where, and why? The Politics of Urban Resilience. Urban Geogr. 2016, 3638, 1-21. [CrossRef]

38. Fainstein, S. Resilience and justice. Int. J. Urban Reg. Res. 2015, 39, 157-167. [CrossRef]

39. Mang, P.; Reed, B. Regenerative Development and Design. In Sustainable Built Environments; Loftness, V., Haase, D., Eds.; Springer New York: New York, NY, USA, 2013; pp. 478-501.

40. Russel, J. Thrivability: Breaking through to a World That Works; Triarchy Press: Devon, UK, 2013.

41. Shaw, K. "Reframing" Resilience: Challenges for Planning Theory and Practice. Plan. Theory Pract. 2012, 13, 299-333.

42. Taleb, N.N. Antifragile: Things that Gain from Disorder; Random House: New York, NY, USA, 2012.

43. Kates, R.W.; Travis, W.R.; Wilbanks, T.J. Transformational adaptation when incremental adaptations to climate change are insufficient. Proc. Natl. Acad. Sci. USA 2012, 109, 7156-7161. [CrossRef] [PubMed]

44. Pelling, M. Adaptation to Climate Change: From Resilience to Transformation; Routledge: Abingdon, UK, 2011.

45. Tschakert, P.; St. Clair, A.L. Conditions for transformative change: The role of responsibility, care, and place making in climate change research. In Proceedings of the Transformation in a Changing Climate, Oslo, Norway, 19-21 June 2013; University of Oslo, Ed.; University of Oslo: Oslo, Norway, 2013; pp. 267-275.

46. Béné, C.; Wood, R.G.; Newsham, A.; Davies, M. Resilience: New Utopia or New Tyranny? Reflection about the Potentials and Limits of the Concept of Resilience in Relation to Vulnerability Reduction Programmes; Wiley: New York, NY, USA, 2012. 
47. Marshall, N.A. Understanding social resilience to climate variability in primary enterprises and industries. Glob. Environ. Chang. 2010, 20, 36-43. [CrossRef]

48. Vincent, K. Uncertainty in adaptive capacity and the importance of scale. Glob. Environ. Chang. 2007, 17, 12-24. [CrossRef]

49. Hahn, M.B.; Riederer, A.M.; Foster, S.O. The Livelihood Vulnerability Index: A pragmatic approach to assessing risks from climate variability and change-A case study in Mozambique. Glob. Environ. Chang. 2009, 19, 74-88. [CrossRef]

50. Cinner, J.E.; McClanahan, T.R.; Graham, N.A.J.; Daw, T.M.; Maina, J.; Stead, S.M.; Wamukota, A.; Brown, K.; Bodin, Ö. Vulnerability of coastal communities to key impacts of climate change on coral reef fisheries. Glob. Environ. Chang. 2012, 22, 12-20. [CrossRef]

51. Engle, N.L.; Lemos, M.C. Unpacking governance: Building adaptive capacity to climate change of river basins in Brazil. Glob. Environ. Chang. 2010, 20, 4-13. [CrossRef]

52. Eakin, H.C.; Lemos, M.C.; Nelson, D.R. Differentiating capacities as a means to sustainable climate change adaptation. Glob. Environ. Chang. 2014, 27, 1-8. [CrossRef]

53. Miller, F.; Osbahr, H.; Boyd, E.; Thomalla, F.; Bharwani, S.; Ziervogel, G.; Walker, B.; Birkmann, J.; Van der Leeuw, S.; Rockström, J.; et al. Resilience and vulnerability: Complementary or conflicting concepts? Ecol. Soc. 2010, 15, 11. Available online: http:/ /www.ecologyandsociety.org/vol15/iss3/art11/ (accessed on 29 July 2016).

54. Olsson, P.; Bodin, Ö.; Folke, C. Building transformative capacity for ecosystem stewardship in social-ecological systems. In Adaptive Capacity and Environmental Governance; Plummer, R., Armitage, D., Eds.; Springer Verlag: New York, NY, USA, 2010; pp. 263-286.

55. Armitage, D.; Béné, C.; Charles, A.T.; Johnson, D.; Allison, E.H. The interplay of well-being and resilience in applying a social-ecological perspective. Ecol. Soc. 2012, 17, 15. Available online: http://www. ecologyandsociety.org/vol17/iss4/art15/ (accessed on 29 July 2016). [CrossRef]

56. Ensor, J.E.; Park, S.E.; Hoddy, E.T.; Ratner, B.D. A rights-based perspective on adaptive capacity. Glob. Environ. Chang. 2015, 31, 38-49. [CrossRef]

57. White, S.C. Analysing wellbeing: A framework for development practice. Dev. Pract. 2010, 20, $158-172$. [CrossRef]

58. Shackleton, S.; Ziervogel, G.; Sallu, S.; Gill, T.; Tschakert, P. Why is socially-just climate change adaptation in sub-Saharan Africa so challenging? A review of barriers identified from empirical cases. WIRES Clim. Chang. 2015, 6, 321-344. [CrossRef]

59. O'Brien, K.; Wolf, J. A values-based approach to vulnerability and adaptation to climate change. Wiley Interdiscip. Rev. Clim. Chang. 2010, 1, 232-242. [CrossRef]

60. Rogers, D.S.; Duraiappah, A.K.; Antons, D.C.; Munoz, P.; Bai, X.; Fragkias, M.; Gutscher, H. A vision for human well-being: Transition to social sustainability. Curr. Opin. Environ. Sustain. 2012, 4, 61-73. [CrossRef]

61. Ziervogel, G.; Van Garderen, E.A.; Price, P. Strengthening the science-policy interface by co-producing an adaptation plan: Leveraging opportunities in Bergrivier municipality, South Africa. Environ. Urban. 2016. Available online: http://eau.sagepub.com/content/early/2016/07/15/ 0956247816647340.abstract (accessed on 5 August 2016).

62. Shi, L.; Chu, E.; Anguelovski, I.; Aylett, A.; Debats, J.; Goh, K.; Schenk, T.; Seto, K.C.; Dodman, D.; Roberts, D.; et al. Roadmap towards justice in urban climate adaptation research. Nat. Clim. Chang. 2016, 6, 131-137. [CrossRef]

63. Hughes, S. Justice in urban climate change adaptation: Criteria and application to Delhi. Ecol. Soc. 2013, 18, 48. Available online: http://www.ecologyandsociety.org/vol18/iss4/art48/ (accessed on 29 July 2016). [CrossRef]

64. Pelling, M.; High, C. Understanding adaptation: What can social capital offer assessments of adaptive capacity? Glob. Environ. Chang. 2005, 15, 308-319. [CrossRef]

65. Adger, N. Social Capital, Collective Action, and Adaptation to Climate Change. Econ. Geogr. 2003, 79, 387-404. [CrossRef]

66. Rock, D. SCARF: A Brain-Based Model for Collaborating with and Influencing Others. Neuroleadersh. J. 2008, 1, 78-87.

67. Hobbes, T. The Leviathan Parts I and II; Martinich, A.P., Ed.; Broadview Press: Peterborough, ON, Canada, 2005. 
68. Scharmer, C.O. Theory U: Leading from the Future as It Emerges; Berrett-Koehler Publishers: Oakland, CA, USA, 2007.

69. Harari, Y.N. Sapiens-A Brief History of Humankind; Harper: New York, NY, USA, 2015.

70. Folke, C.; Gunderson, L. Reconnecting to the Biosphere: A Social-Ecological Renaissance. Ecol. Soc. 2012, 17, 55. Available online: http://www.ecologyandsociety.org/vol17/iss4/art55/ (accessed on 29 July 2016). [CrossRef]

71. Brown, R. Impediments to Integrated Urban Storm Water Management: The Need for Institutional Reform. Environ. Manag. 2005, 36, 455-468. [CrossRef] [PubMed]

72. Dietz, T.; Burns, T.R. Human Agency and the Evolutionary Dynamics of Culture. Acta Sociol. 1992, 35, 187-200. [CrossRef]

73. King, M.L. Where Do We Go from here? The King Insitute. Available online: https://kinginstitute.stanford. edu/king-papers/documents/where-do-we-go-here-delivered-11th-annual-sclc-convention (accessed on 20 August 2016).

74. Scranton, R. Learning How to Die in the Anthropocene; City Lights Publishers: San Francisco, CA, USA, 2015.

75. Wilber, K. Sex, Ecology, Spirituality: The Spirit of Evolution; Shambhala: Boston, MA, USA, 1995.

76. Jacobs, J. The Death and Life of Great American Cities; Random House: New York, NY, USA, 1960.

77. Putnam, R.D. Bowling Alone: America's Declining Social Capital. J. Democr. 1995, 6, 65-78. [CrossRef]

78. Hamdi, N. Small Change: About the Art of Practice and the Limits of Planning in Cities; Earthscan: London, UK, 2004.

79. Google Maps. Available online: https://www.google.co.za/maps?source=tldsi\&hl=en (accessed on 18 September 2016).

80. Bergrivier Municipality Bergrivier Local Municipality. Overview; Western Cape Government: Cape Town, South Africa, 2005.

81. Nel, E. Local economic development in South African small towns. In Local Economic Development in the Developing World. The Experience of Southern Africa; Nel, E., Rogerson, C.M., Eds.; Transaction: London, UK, 2005; pp. 253-266.

82. Boyer, E. The Scholarship of Engagement. J. Public Serv. Outreach 1996, 1, 11-20. [CrossRef]

83. Hadorn Hirsch, G.; Hoffmann-Riem, H.; Biber-Klemm, S.; Grossenbacher-Mansuy, W.; Joye, D.; Pohl, C.; Wiesmann, U.; Zemp, E. Handbook of Transdisciplinary Research; Springer: Berlin, Germany, 2008.

84. Nicolescu, B. Manifesto of Transdisciplinarity; State University of New York Press: Albany, NY, USA, 2001.

85. Stein, Z. Modeling the Demands of Interdisciplinarity: Toward a Framework for Evaluating Interdisciplinary Endeavors Introduction: My Agenda. Integral Rev. 2007, 4, 91-107.

86. O'Brien, K.; Hochachka, G. Integral adaptation to climate change. Integr. Theory Pract. 2010, 5, 89-102.

87. Agbor, J.; Taiwo, O.; Smith, J. Sub-Saharan Africa's Youth Bulge: A Demographic Dividend or Disaster. In Foresight Africa: Top Priorities for the Continent in 2012; The Brookings Institution: Washington, DC, USA, 2012; pp. 9-11.

88. Bollier, D. Bologna. A Laboratory for Urban Commoning. Available online: http://bollier.org/blog/bolognalaboratory-urban-commoning (accessed on 1 May 2016).

(C) 2016 by the authors; licensee MDPI, Basel, Switzerland. This article is an open access article distributed under the terms and conditions of the Creative Commons Attribution (CC-BY) license (http://creativecommons.org/licenses/by/4.0/). 